\title{
Forage quality thresholds for Saiga antelope in a semi-desert rangeland
}

\section{Boris D. Abaturov \& Andrey E. Subbotin*}

\begin{abstract}
Levels of digestibility and protein content necessary for maintenance, weight gain and lactation were estimated for Saiga antelope (Saiga tatarica). Estimates were based on results of digestionbalance trials using confined animals, and feeding trials involving tractable animals at pasture. Threshold parameters were estimated by regression of metabolizable energy intake and body weight gain, food digestibility and metabolic energy intake, protein content in food and the amount of consumed digestible protein. To meet maintenance requirements, food digestibility must be $\geq 59 \%$, with protein content $\geq 7.7 \%$. To meet requirements for growth and lactation, minimum digestibility must be $61-68 \%$, with protein content $\geq 14 \%$. When feeding on native semi-desert range, free-ranging Saiga antelope can meet these nutritional thresholds only through selective foraging. Therefore, when evaluating grazing capacity of Saiga habitat it is important to take into consideration that only a small portion of the total plant biomass is comprised of plants and plant parts of sufficient quality.
\end{abstract}

KEY WORDS: threshold levels, maintenance requirements, Saiga tatarica, body weight, energy in-take, protein content, diet quality, forage selectivity.

Boris D. Abaturov [abaturovbd@mail.ru, abaturov@sevin.ru], Severtsov Institute of Ecology and Evolution, Russian Academy of Sciences, Leninsky prospect 33, Moscow 119071, Russia; Andrey E. Subbotin [andrey.subbotin @gmail.com], All-Russian Research Institute for Nature Conservation, "Znamenskoye-Sadki” Estate, Moscow 117628, Russia.

\section{Критические уровни качества кормов у сайгаков на естественном пастбище в полупустыне}

\author{
Б.Д. Абатуров, А.Е. Субботин
}

РЕЗЮМЕ: Определены уровни переваримости и содержания протеина, необходимые для поддержания жизнедеятельности, роста и лактации у сайгаков (Saiga tatarica). Оценки основаны на результатах балансовых опытов с использованием клеточных животных и опытов по питанию прирученных животных на пастбище. Критические параметры определены регрессионным анализом соотношения количества поглощенной обменной энергии и привеса тела, переваримости корма и количества обменной энергии, содержания протеина в корме и количества потребленного переваримого протеина. Для обеспечения поддержания жизнедеятельности переваримость должна составлять $\geq 59 \%$, содержание протеина $\geq 7,7 \%$. Для обеспечения роста и лактации минимальная переваримость составляет 61-68\% при содержании протеина $\geq 14 \%$. При потреблении кормов на естественном полупустынном пастбище свободнопасущимися сайгаками данные кормовые параметры могут быть обеспечены только избирательностью питания. Вследствие этого при оценке пастбищной емкости местообитаний сайгаков крайне важно учитывать, что только малая доля общей растительности массы включает в себя растения и их части, обладающие необходимым кормовым качеством.

КЛЮЧЕВЫЕ СЛОВА: критические уровни, требования к поддержанию жизнедеятельности, Saiga tatarica, вес тела, потребление энергии, содержание протеина, качество корма, кормовая избирательность.

\section{Introduction}

The tendency of ruminant herbivores to choose the more nutritious foods available to them is a widely known phenomenon. Even when food is abundant, it may not satisfy nutritional needs of animals if its quality is low (Bell, 1971; Robbins, 1983; Berry \& Louw,
1982; Eisfeld, 1985; Abaturov \& Magomedov, 1988; Owen-Smith \& Cooper, 1989; Abaturov et al., 1996; Cook et al., 1996; Sinclair et al., 2006). Data show that free ranging herbivorous mammals are fairly sensitive to changes in nutritional value of their plant food, especially with respect to its digestibility and protein content (Eisfeld, 1974, 1985; Mould \& Robbins, 1981; 
Sinclair et al., 1982; Arnold, 1985; Regelin et al., 1987; Jiang \& Hudson, 1992; Cook, 1996). Nevertheless, the nutritional ecology of many wild ruminants remains poorly understood. Precise knowledge of forage availability, and especially its quality, is crucial for understanding mechanisms of animal distribution, movements, and forage use patterns, as well as reproductive performance of animals in free-ranging populations. Among Eurasian species, Saiga antelope (Saiga tatari$c a$ L.) are susceptible to nutritional deprivation based on their body allometry and productivity of their native habitats (Abaturov et al., 1998). Here we present analyses of qualitative parameters, including forage digestibility and protein content that are relevant to assessing the suitability of habitats to support Saiga antelope. Conservation of Saiga antelope populations and proactive management of the species' habitat requires explicit knowledge of their nutritional requirements (Abaturov, 2007). In this paper we investigate nutritional thresholds, which managers can use to evaluate the suitability, or carrying capacity, of various semi-desert habitats in terms of their ability to meet the nutritional needs of this herbivore.

\section{Study area}

We analyzed the data obtained in the field researches conducted in 1978-1980; 1995-1996, and 20022004 at the Dzhanybek Biological Field Station of the Institute of Forest Science, Russian Academy of Sciences. The Station located in the Northern Precaspian depression on the Russia-Kazakhstan administrative border. The study area occupies a contemporary range of Saiga antelope and represents typical clay semidesert landscape with a complex of three-component soil and vegetation cover (Gordeeva \& Larin, 1965; Bol'shakov \& Bazykina, 1974; Abaturov et al., 1998). Thus the territory includes desert, semi-desert and steppe plant communities. The deserted communities occupy the basic portion of plain, with a total 28 plant species among which Kochia prostrata, Poa bulbosa, Tulipa gesneriana, Leimus ramosus, Artemisia pauciflora, Salsola laricina predominate. Semi-desert communities include 40 species. Key dominants here are Agropyron desertorum, Tanacetum achilleifolium, Galatella villosa, G. tatarica, Limonium sareptanum, Tulipa biebersteiniana, T. biflora. Steppe associations include 80 species of vascular plants with a key predominance of Stipa capillata, S. Lessingiana, Festuca valesiaca, Agropyron cristatum, alfalfa Medicago falcate, Galium verum and others steppe species.

\section{Material and methods}

The groups of 2 to 6 tractable Saiga antelopes have been trialed in these studies. We used these animals to examine the nutritional ecology of Saiga via two approaches. The first approach involved direct estimates of nutrition relations using traditional digestion-bal- ance trials during which the animals were fed rations of known composition while held captive in balance cages libitum (Fig. 1). The second approach was based on using fecal bags on free-ranging animals on native pasture (Fig. 1). The 3 animals were permanently employed in 13 digestion-balance trials of 6 different diets. The 2 animals were employed in 9 grazing trials in 4 differing habitats and all of the year-round seasons. Detailed descriptions of research methods were provided in the previous publications (Abaturov et al., 1982, 1997, 2003).

\section{Digestion-Balance Trials}

Studies in digestive-balance cages allowed us to estimate daily food consumption and digestibility of different diets of known botanical and chemical compositions. These diets were comprised of Kochia prostrata, Agropyron species (sowing), a combination of forbs that are common on areas frequented by saiga in May and July, leaves of elm (Ulmus pumila), mix of grasses and dried alfalfa with ground barley grain. In the course of each experiment animals were periodically weighed to record any changes in their body weight. Each trial lasted 5-11 days, with an additional preliminary period of 2-3 days to allow for animal adaptation to each new diet. Animals were fed ad libitum. Non-fed forage and feces were gathered and dried at $90^{\hat{\imath}} \tilde{\mathrm{N}}$ to constant weight.

\section{Grazing Trials}

Grazing trials were conducted during different seasonal periods to reflect changes in plant phenology: early spring, when the first sprouts of plants appear (April 12-17); late spring, when ephemerous and ephemeroid plants desiccate (end of May); early summer, when vegetation is at its maximum development (June 19-25); mid-summer, when the majority of steppe gramineous plants and forbs desiccate (July 20-30); late summer, when active growth of the predominant plant species (Chenopodiaceae, Euphorbiaceae, Leguminosae) proceeds (August-September); autumn, when nearly all plant growth has ended (end of September); and in winter, when only senescent plant biomass was available (December 5-10). Prior to each grazing trial the experimental animals were allowed to adapt to the experimental pastures over a period of 3-5 days. Each grazing trial lasted 4-6 days, during which the experimental animals were observed at pasture continuously and permanently, and each 10 minutes the type of their activity (grazing, rest laying, walking) has been registered.

The number of animals observed in each separate trial, varied from 1 to 2 . During each observation period, the experimental animal was tethered but allowed to graze freely within the experimental area of $1130 \mathrm{~m}^{2}$ in size. The ranging area has been rotated to exclude overgrazing for 3-4 times a day.

Botanical composition of grazed diets was determined by visual counts of the number of experimental 


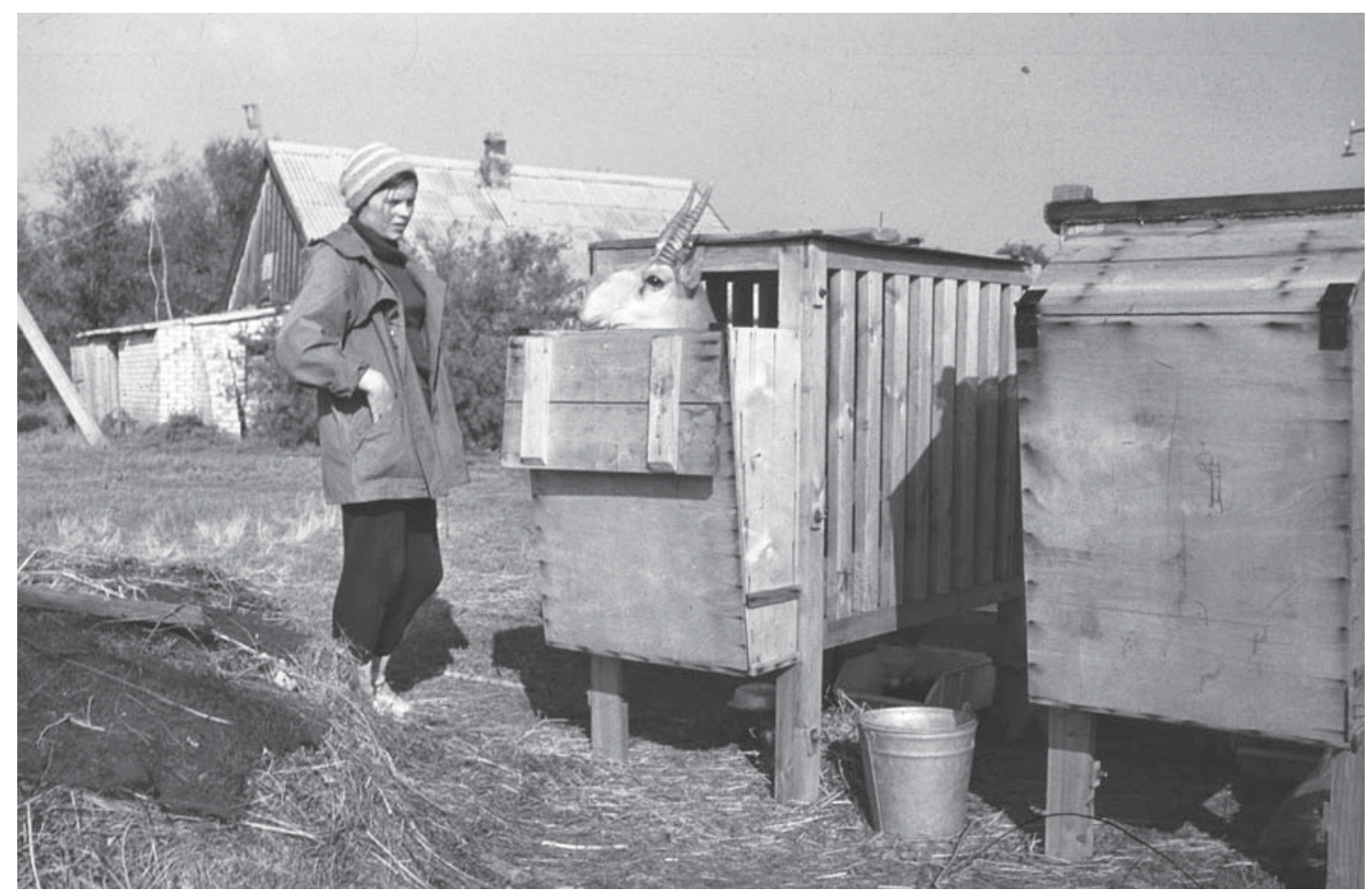

A

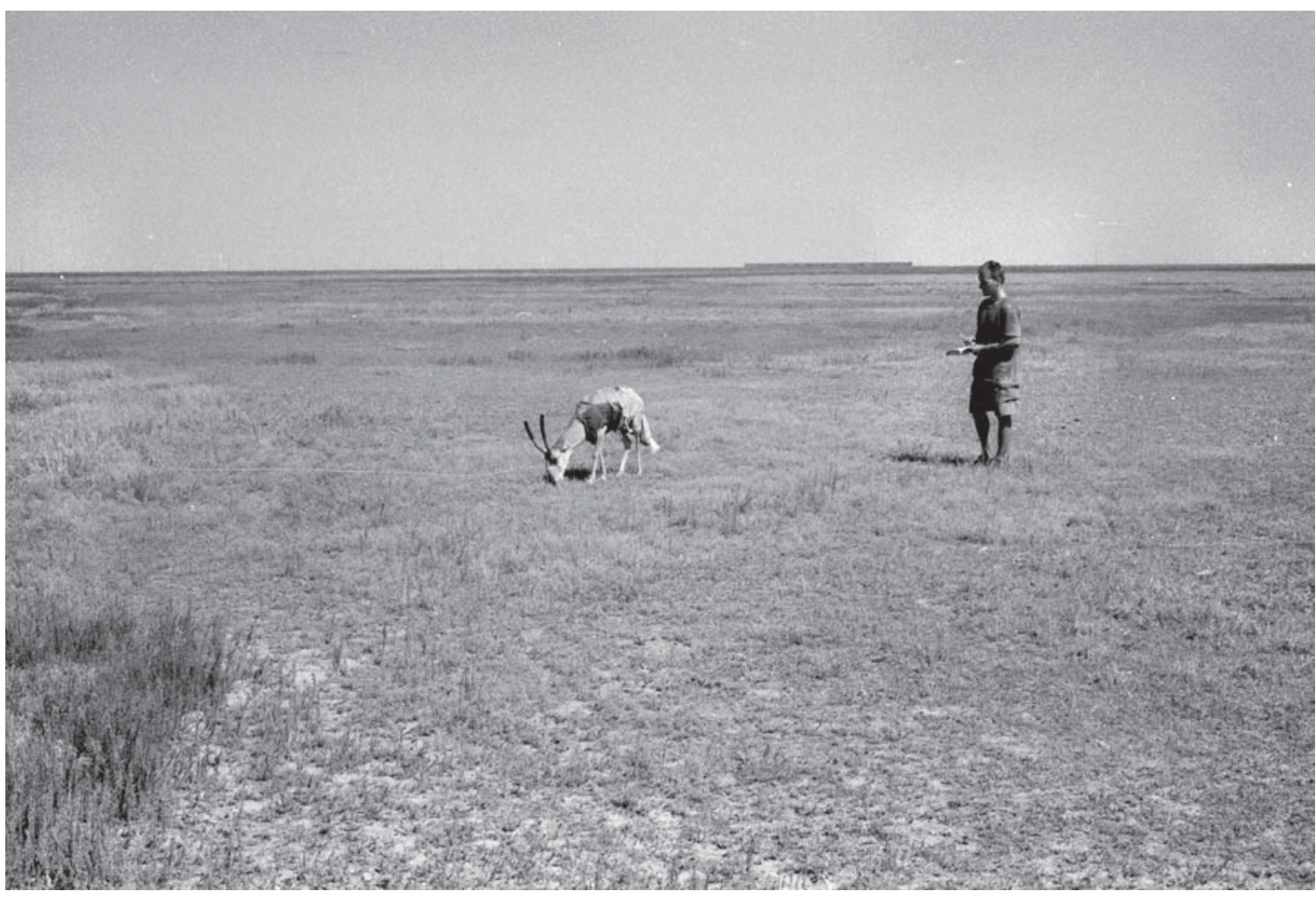

Figure 1. Trials of nutritional ecology of tame Saiga antelopes: A — in balance cages, B — free-grazing in native pasture with fecal bags. 
animals bites took from each plant species. Bite counts were conducted during the entire ranging period from a distance of 2-3 m (Fig. 1). Botanical composition of diet was calculated on the proportion of total bites attributed to each species.

In the course of each grazing trial animals were weighed daily at the same time of day.

\section{Estimation of Intake and Dietary Quality}

Daily food consumption (C, g/animal, dry matter) was calculated as $F \times 100 /(100-\mathrm{D})$, where

$F$ is the daily portion of feces (g/animal, dry matter), and $D$ is the coefficient of dry matter digestibility (\%). Daily amount of feces was determined using fecal bags. We inferred digestibility of saiga diets from the ratio between the concentration of inert substances in food and in feces (Gallup et al., 1945; Streeter, 1969), using Organogenic Silica and also lignin in plant matter as the inert indicators. Concentration of the inert substantes in a diet was calculated taking into account a share of each plant species consumed in the diet and the content of inert substantes in them. The digestibility of dry matter $(D, \%)$ and separate nutrients $\left(D^{\prime}, \%\right)$ were calculated as $D=(1-v / f) \times 100 ; D^{\prime}=100-(100 \times v / f \times a / d)$, where $v$ and $f$ are silica and lignin concentration in food and in feces respectively, and $a$ and $b$ are investigated nutrients concentration in feces and in food, respectively. Silicon and lignin excreted in feces of saiga antelope comprises $97.4-99.5 \%$ of the total silicon consumed with forage and 93.0-98.3 of the total lignin consumed (Abaturov et al., 1997). We analyzed organogenic silicon with acid hydrolyses using $\mathrm{HNO}_{3}$, which excludes silicon in plant food that originates from soil and dust (Kolesnikov \& Abaturov, 1997). Chemical composition of nutrients in forage plants and feces was determined by standard methods (Instruction for zonal agrochemical laboratories analysis of forage and plants) (Anon., 1968).

Energy value of food was estimated by multiplying the amount of different nutritional components by their energy equivalent: protein - $18.9 \mathrm{~kJ}$, lipids - 39.0; carbohydrates - 17.6. To convert digestible energy into metabolic energy we used a conversion coefficient of 0.87 (McDonald et al., 1969; Kaloshnikov \& Kleimenov, 1985).

In this study we defined the metabolic energy requirement for maintenance to include energy expenditure in resting and grazing activities at zero weight balance (i.e., maintenance of energy equilibrium of free existence) was estimated by regression analyses of daily metabolic energy intake $\left(\mathrm{kJ} / \mathrm{kgBW}^{0.75}\right)$ on daily weight gain of an animal $\left(\mathrm{g} / \mathrm{kgBW}^{0.75}\right)$. Digestibility parameters for different energy needs (grazing activity, weight gain, lactation) were estimated by regression analyses of daily consumption of metabolic energy $\left(\mathrm{kJ} / \mathrm{kgBW}^{0.75}\right)$ on digestibility of forage dry matter (DMD\%).

Minimum nitrogen requirements for maintenance were calculated as the sum of fecal metabolic nitrogen and endogenous urinary nitrogen. Metabolic fecal nitrogen was calculated by regression of dietary protein content $(\%)$ on the amount of apparent digestible protein in the consumed forage $(\mathrm{g} / 100 \mathrm{~g}$ of forage, after Robbins, 1983). Endogenous urinary nitrogen was assumed equal to $0.12 \mathrm{~g} / \mathrm{kgBW}^{0.75}$ (Agricultural Research Council, 1965; Eisfeld, 1974; Robbins et al., 1974; Robbins, 1983; Schwartz et al., 1987). Protein requirements for growth and lactation of saiga antelope were assumed equal to those of domestic sheep (Agricultural Research Council, 1965; MacDonald et al., 1969). Threshold levels of protein concentration in forage were estimated by linear regression of daily intake of digestible protein $\left(\mathrm{g} / \mathrm{kgBW}^{0.75}\right)$ on dietary protein content $(\%)$.

\section{Results}

\section{Botanical Composition of Diets}

The composition of diet in traditional digestionbalance trials (in balance cages) as it was noted above, consisted of separate plant species (Kochia prostrata, sown Agropyron, leaves of elm), barley grain and their mixtures. In grazing trials free-ranging animals have actively chosen the most nutritious plants and their parts in all cases. Despite of the rich vegetation diversity of the grazing areas (more than 100 plant species) the composition of the diet in all cases and different seasons included only several species particularly Kochia prostrata (up to $60 \%$ of a diet), alfalfa (up to $28 \%$ ), the Galatella villosa, and G. tatarica (up to $25 \%$ ). In early spring these were sprouts of tulip (Tulipa spp.) (88\%); in early summer in steppe associations these were $\mathrm{Po}$ tentilla bifurca (67\%); and in late summer - Artemisia austriaca $(58 \%)$. Proportion of other species of forbs was less and did not exceed $10 \%$. It is important to note, that gramineous plants in all grazing trials were practically absent in a diet (Abaturov et al., 1998, 2005).

\section{Chemical Composition of Diets}

In the digestion-balance trials, sown Agropyron, barley grain, and elm leaves had the highest nutritional value, while Kochia and hay were of lower quality (Tab. 1). Protein and energy content were greatest in the sown Agropyron. Crude fiber was lowest in barley and similarly low in the elm leaves. Ash was lowest in the barley ration. Crude fat was greatest in elm leaves.

In contrast to the nutrient differences observed among rations fed in the digestion-balance trials, apparent nutrient quality of diets observed during the grazing trials (Tab. 1). The highest protein content was recorded in the early spring grazing trial (18.4\%), when animals foraged primarily on sprouts of tulip (Tab. 1). Digestibility varied substantially among diets, from 50\% (Kochia) to 75-77\% (forbs and grain mix, spring forbs shoots in case of free grazing) (Tab. 2).

\section{Intake of Dry Matter and Energy}

Intake of dry matter and energy varied considerably among diets and seasons (Tab. 2). Daily intake of dry 
Table 1 . Chemical composition of saiga consumed forage ( $\%$ of dry matter).

\begin{tabular}{|c|c|c|c|c|c|c|c|}
\hline Type of food & Date & $\begin{array}{c}\text { Crude } \\
\text { protein }\end{array}$ & $\begin{array}{c}\text { Crude } \\
\text { lipids }\end{array}$ & $\begin{array}{c}\text { Crude } \\
\text { fibre }\end{array}$ & $F E$ & $\begin{array}{c}\text { Crude } \\
\text { ash }\end{array}$ & $\begin{array}{c}\text { Energy } \\
(\mathrm{kJ} / \mathrm{g})\end{array}$ \\
\hline Crashed barley grain & - & 16.7 & 2.10 & 4.5 & 72.6 & 4.07 & 16.88 \\
\hline Alfalfa hay & - & 12.5 & 3.09 & 27.6 & 46.9 & 9.14 & 16.84 \\
\hline Kochia prostrata & May & 11.3 & 1.19 & 24.5 & 54.0 & 8.70 & 16.47 \\
\hline $\begin{array}{c}\text { Sown Agropyron } \\
\text { (juvenile greens) }\end{array}$ & May & 21.1 & 3.37 & 24.1 & 51.4 & 10.5 & 19.00 \\
\hline $\begin{array}{c}\text { Leaves of elm } \\
\text { (Ulmus pumila) }\end{array}$ & August & 12.8 & 5.22 & 8.4 & 68.3 & 13.7 & 17.35 \\
\hline \multirow{5}{*}{\begin{tabular}{c} 
Green herb in diet \\
\cline { 2 - 9 }
\end{tabular}} & April 12-17 & 18.4 & 2.70 & 27.1 & 46.8 & 4.84 & 17.53 \\
\cline { 2 - 9 } & May 26-29 & 14.8 & 2.80 & 29.6 & 46.4 & 6.20 & 17.29 \\
\cline { 2 - 9 } & June 2-6 & 14.3 & 2.70 & 29.8 & 46.0 & 5.64 & 17.37 \\
\cline { 2 - 8 } & July 27-30 & 14.2 & 2.77 & 32.1 & 45.1 & 5.76 & 17.35 \\
\cline { 2 - 8 } & August 3-6 & 12.6 & 2.60 & 30.5 & 46.9 & 7.42 & 17.04 \\
\cline { 2 - 8 } & August 28-31 & 12.7 & 2.60 & 29.50 & 48.65 & 7.16 & 17.06 \\
\cline { 2 - 8 } & September 21-27 & 13.3 & 2.69 & 32.9 & 45.7 & 6.16 & 17.22 \\
\cline { 2 - 8 } & December 1-4 & 13.4 & 2.59 & 30.1 & 48.0 & 6.03 & 17.29 \\
\hline
\end{tabular}

matter in summer ranged from $45 \mathrm{~g} / \mathrm{kg}(\mathrm{BW})^{0.75}$ in the case of sown Agropyron, up to $117 \mathrm{~g} / \mathrm{kg}(\mathrm{BW})^{0.75}$ in the case of grain mixed with grass or hay in cage trials or in the case of forbs in grazing trials. It should be noted that low consumption of sown Agropyron occurred despite high digestibility of this forage (64-66\%). Agropyron was not dried prior to feeding and thus contained high moisture content (up to $80 \%$ ). The high moisture content in consumed forage contributed to gut fill, and to low dry matter consumption (Abaturov et al., 1982). In summer, daily metabolic energy intake varied from 470 $\mathrm{kJ} / \mathrm{kg}(\mathrm{BW})^{0.75}$ in the case of Kochia in the cage trials, to $1270 \mathrm{~kJ} / \mathrm{kg}(\mathrm{BW})^{0.75}$ in the case of forbs in the grazing trials. In winter, daily intake of forage dry matter and metabolic energy were considerably lower than in summer (as low as $42.3 \mathrm{~g} / \mathrm{kg}(\mathrm{BW})^{0.75}$ and $380 \mathrm{~kJ} / \mathrm{kg}$ $\left.(\mathrm{BW})^{0.75}\right)$.

\section{Food Digestibility as an Indicator of Sufficient}

\section{Energy Intake}

To estimate maintenance energy expenditures and energy costs of weight gain, we analyzed the relationship between metabolic energy intake $(y)$ and the amount of weight gain $(x)$. Regression analyses showed that relationship between these two parameters is practically identical for confined and free-ranging animals, suggesting that animal activity and overall energy expenditure in the digestion-balance cages were fairly similar to those in the grazing trials that were conducted at pasture. Thus, the correlation between the amounts of daily metabolic energy intake and weight gain of animals can be presented in the form of regression equation $y=10.46+719.1$ (Fig. 2). According to the equation, saiga maintenance energy requirements at zero balance level in summer on the pasture equals 719 $\pm 34.2 \mathrm{~kJ} / \mathrm{kg}(\mathrm{BW})^{0.75}$. In winter, the slope of this relation is considerably lower: based on data from three winter experiments (in cages and on the pasture) it equals ap- proximately $500 \mathrm{~kJ} / \mathrm{kg}(\mathrm{BW})^{0.75}$ (Tab. 2). In a review by Hudson and Christopherson (1985) estimates of maintenance energy at rest for 5 species (Odocoileus hemionus, Capreoulus capreolus, Cervus elaphus, Alces alces, Rangifer tarnadus and Antilocapra americana) varied in adult individuals from $523-655 \mathrm{~kJ} / \mathrm{kg}(\mathrm{BW})^{0.75}$ in summer to $476-597 \mathrm{~kJ} / \mathrm{kg}(\mathrm{BW})^{0.75}$ in winter. In case of Saiga antelope, setting the adjustment for foraging activity that varied between 1.18 and 1.24 (Abaturov et $a l ., 1998)$, expenditures of saigas for maintenance energy at rest appear to make close figures: $594 \mathrm{~kJ} / \mathrm{kg}(\mathrm{BW})$ in the summer and $413 \mathrm{~kJ} / \mathrm{kg}(\mathrm{BW})$ in the winter.

Thus, according to our experimental data, saiga's daily metabolic energy expenditure for maintenance at zero body weight balance, which reflects maintenance energy requirements of grazing animal, equals $0.72 \mathrm{MJ} /$ $\mathrm{kg}(\mathrm{BW})^{0.75}$ during the warm season and $0.50 \mathrm{MJ} / \mathrm{kg}$

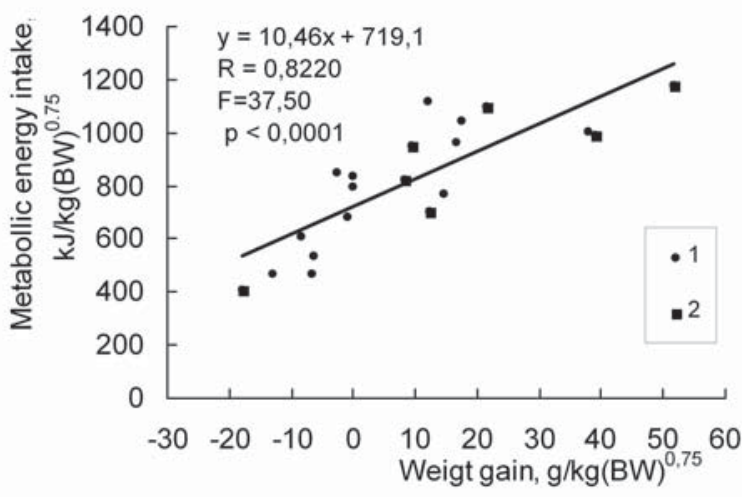

Figure 2. Relationship $(y=b x+a)$ between daily metabolic energy intake $\left(\mathrm{kJ}^{\mathrm{k}} / \mathrm{kg}^{0.75}\right.$ body weight) and daily live weight gain ( $\mathrm{g} / \mathrm{kg}^{0.75}$ body weight) of saiga based on data from experiments in warm season with animals in balance cages (1) and free ranging animals (2). Std. Error: $\mathrm{a}=34.17, \mathrm{~b}=1.70$. Plevel $<0.00001$. 
Table 2. Experimental nutrition parameters and weight gain of caged and free-ranging saiga antelope.

\begin{tabular}{|c|c|c|c|c|c|c|c|c|}
\hline \multirow{3}{*}{$\begin{array}{c}\text { Forage } \\
\text { composition }\end{array}$} & \multirow[t]{3}{*}{ Date } & \multirow[t]{3}{*}{ Sex } & \multirow{3}{*}{$\begin{array}{c}\text { Body } \\
\text { weight } \\
\mathrm{kg}\end{array}$} & \multirow{3}{*}{$\begin{array}{l}\text { Weight } \\
\text { gain, } \\
\text { g/ } \\
\text { animal/ } \\
\text { day }\end{array}$} & \multirow{3}{*}{$\begin{array}{l}\text { Dige- } \\
\text { sti- } \\
\text { bility, } \\
\%\end{array}$} & \multicolumn{3}{|c|}{ Daily intake } \\
\hline & & & & & & \multicolumn{2}{|c|}{ Dry matter } & \multirow{2}{*}{$\begin{array}{c}\text { Metabolic } \\
\text { energy, } \mathrm{kJ} / \\
\mathrm{kgBW}^{0.75}\end{array}$} \\
\hline & & & & & & $\begin{array}{l}\mathrm{g} / \text { ani- } \\
\text { mal }\end{array}$ & $\begin{array}{c}\mathrm{g} / \mathrm{kg} \\
\mathrm{BW}^{0.75}\end{array}$ & \\
\hline \multicolumn{9}{|c|}{ Warm time of the year } \\
\hline \multirow{2}{*}{$\begin{array}{l}\text { Steppe herbs and } \\
\text { barley grain* }\end{array}$} & $5 / 13-19$ & Male & 34.2 & 164 & 75 & 1280 & 90.8 & 1118 \\
\hline & $7 / 7-15$ & Male & 34.7 & 250 & 68 & 1505 & 105.2 & 1046 \\
\hline \multirow{4}{*}{$\begin{array}{l}\text { Alfalfa hay and } \\
\text { barley grain* }\end{array}$} & $8 / 1-6$ & Female & 22.4 & 150 & 64 & 843 & 81.8 & 767 \\
\hline & $5 / 6-12$ & Male & 32.8 & 229 & 73 & 993 & 72.4 & 962 \\
\hline & 9/19-26 & Male & 39.4 & -42.8 & 70 & 1253 & 79.8 & 853 \\
\hline & $9 / 19-26$ & Female & 32.2 & 0 & 68 & 952 & 70.4 & 797 \\
\hline Steppe herbs* & $7 / 18-24$ & Male & 32.0 & - & 54 & 1165 & 86.6 & 822 \\
\hline \multirow[t]{2}{*}{ Sown Agropyron* } & $5 / 12-20$ & Male & 28.8 & -102 & 64 & 637 & 51.4 & 611 \\
\hline & $5 / 12-20$ & Female & 25.5 & -73 & 66 & 511 & 45.2 & 537 \\
\hline \multirow[t]{3}{*}{ Kochia prostrata* } & $6 / 13-18$ & Male & 29.9 & -14 & 53 & 1037 & 81.0 & 685 \\
\hline & $6 / 1-7$ & Female & 26.8 & -80 & 52 & 744 & 63.0 & 470 \\
\hline & $6 / 4-9$ & Female & 23.0 & -138 & 49 & 700 & 66.7 & 472 \\
\hline Elm leaves* & $8 / 10-15$ & Female & 27.3 & 0 & 57 & 948 & 79.7 & 839 \\
\hline \multirow{8}{*}{$\begin{array}{l}\text { Green herb in diet } \\
\text { (free grazing) }{ }^{* *}\end{array}$} & $4 / 12-17$ & Female & 20.0 & - & 77 & 986 & 104.2 & 1270 \\
\hline & $5 / 26-29$ & Male & 32.0 & 166 & 59 & 1060 & 78.8 & 704 \\
\hline & $6 / 2-6$ & Male & 35.0 & 562 & 68 & 1398 & 97.2 & 993 \\
\hline & $6 / 21-24$ & Female & 22.3 & 530 & 73 & 1054 & 102.7 & 1179 \\
\hline & $7 / 27-30$ & Male & 36.0 & -262 & 51 & 796 & 54.2 & 409 \\
\hline & $8 / 3-6$ & Male & 41.0 & 150 & 56 & 1901 & 117.3 & 948 \\
\hline & $8 / 28-31$ & Female & 26.4 & 250 & 68 & 1207 & 104.1 & 1099 \\
\hline & $9 / 1-27$ & Female & 20.5 & 80 & 57 & 854 & 89.0 & 822 \\
\hline \multicolumn{9}{|c|}{ Cold time of the year } \\
\hline \multirow{2}{*}{$\begin{array}{l}\text { Crashed barley and } \\
\text { alfa alfa hay* }\end{array}$} & $1 / 25-31$ & Male & 36.3 & 4.8 & 71 & 702 & 47.4 & 504 \\
\hline & $3 / 4-8$ & Male & 34.5 & 20 & 71 & 699 & 49.2 & 521 \\
\hline Steppe herbs $* *$ & $12 / 1-4$ & Female & 27.2 & -100 & 56 & 503 & 42.3 & 380 \\
\hline
\end{tabular}

*Feeding in balance cages

** Grazing on natural range

$(B W)^{0.75}$ in winter. Based on regression equation showing relation between saiga weight gain and metabolic energy intake (Fig. 2) an animal uses $10.46 \pm 1.70 \mathrm{~kJ}$ of metabolic energy per 1 gram of body weight gain in addition to energy expenditure for maintenance. It is important to mention that this value is different for saiga compared to other species. Thus for American elk (Cervus elaphus) it varies from 26 to $55 \mathrm{~kJ} / \mathrm{g}$ depending on sex and season. It is lower than $16 \mathrm{~kJ} / \mathrm{g}$ only for calves (Simpson et al., 1978; Fennessy et al., 1981; Suttie et al., 1987; Jiang \& Hudson 1992).

In wild populations of saiga, weight gain has been recorded only during the warm season (Bannikov et al., 1961; Abaturov et al., 1982). During five warm months (May through September), a yearling animal gains on the average $10 \mathrm{~kg}$, i.e. about $65 \mathrm{~g} /$ individual daily $(6 \mathrm{~g} /$ $\left.\mathrm{kg}(\mathrm{BW})^{0.75}\right)$. Based on the equation in Fig. 2, cumulative energy expenditure (for maintenance requirements and growth) is $782 \mathrm{~kJ} / \mathrm{kg}^{0.75}$. If high quality forage is abundant, growth in body mass is usually more rapid. In our experiment with free ranging saiga antelopes, max- imum daily weight gain in June was $530 \mathrm{~g}$ /individual $\left(51 \mathrm{~g} / \mathrm{kg}(\mathrm{BW})^{0.75}\right)$. In this case daily metabolic energy expenditure according to the equation was as high as $1252 \mathrm{~kJ} / \mathrm{kg}(\mathrm{BW})^{0.75}$. In August-September daily weight gain of $21 \mathrm{~g} / \mathrm{kg}(\mathrm{BW})^{0.75}$ required $984 \mathrm{~kJ} / \mathrm{kg}$ of metabolic energy.

There is no data available on the energy required for daily milk production by saiga antelope. However, according to existing data for domestic sheep (Agricultural research council 1965; McDonald et al., 1969) daily metabolic energy requirement of lactating females during the first 10 days of lactation is close to $1000-1020$ $\mathrm{kJ} / \mathrm{kg}(\mathrm{BW})^{0.75}$. Hence, the energy expenditures for lactation are close to maximum energy costs of weight gain.

The amount of metabolic energy ingestion depends mainly on two parameters: the daily intake of food and on its digestibility. As food consumption is limited and is relatively constant, the amount of metabolic energy intake is affected mainly by digestibility, which depends on the quality of forage and varies over a wide 


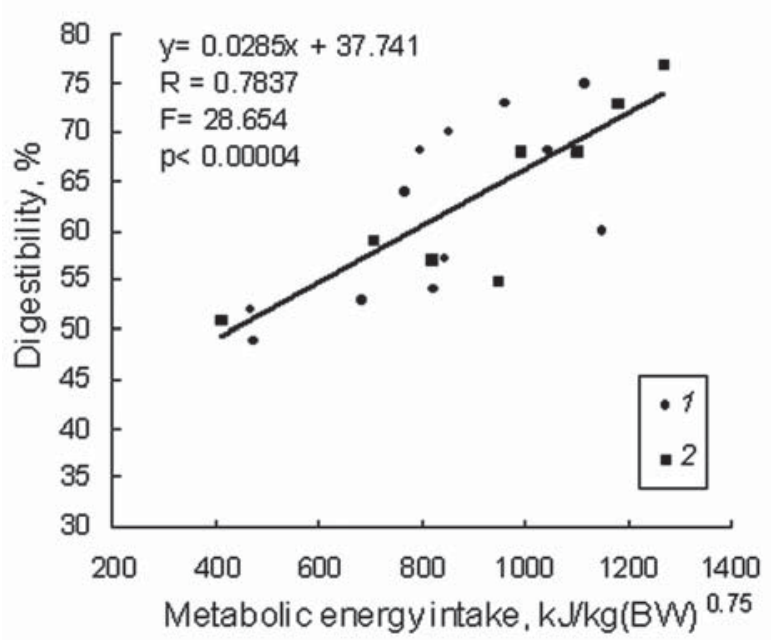

Figure 3. Relationship $(y=b x+a)$ between apparent forage digestibility (\% dry matter) and metabolic energy intake $(\mathrm{kJ} /$ $\mathrm{kg}^{0.75}$ body weight). Data obtained in warm season in experiments with saiga in balance cages (1) and free ranging saiga (2). (Agropyron sp. excluded because its proportion in the ration was considerably lower than normal). Std. Error: $\mathrm{a}=$ $4.80, \mathrm{~b}=0.005$. P-level $<0.0001$.

range. Relationship between ration digestibility $(y)$ and metabolic energy intake $(x)$ in our case can be presented in the form of the following regression equation: $y=$ $0.029 x+37.74$ (Fig. 3). According to the equation the maintenance energy requirements presented above (719 $\mathrm{kJ} / \mathrm{kg}(\mathrm{BW})^{0.75}$ without energy for growth) can be provided only at the forage digestibility level not lower than $59 \%$. This level of digestibility should be considered critical level, providing maintenance level of energy intake and overall positive energy balance for grazing non-breeding animal. To provide for daily weight gain at $6 \mathrm{~g} / \mathrm{kg}(\mathrm{BW})^{0.75}$, which during warm season requires daily metabolic energy intake of $782 \mathrm{~kJ} / \mathrm{kg}$ $(\mathrm{BW})^{0.75}$, food digestibility should be not lower than $61 \%$ according to the above equation.

Higher metabolic energy requirements during lactation (1000-1020 kJ/ $\mathrm{kg}^{0.75}$ ) would accordingly require increase in food digestibility up to $67-68 \%$. Thus in our case, the threshold level of forage digestibility for positive energy balance of adult (full grown) non-breeding saiga is $59 \%$, and if growth and lactation energy requirements are included, it is above $61 \%$ and $68 \%$ respectively.

Provision with protein and threshold concentrations of protein in the forage of saiga antelope

Nitrogen requirements were evaluated using indices of protein consumption and digestibility obtained in our experiments with free ranging animals, and also in three cases of confined animals with feeding to leaves Lactuca tatarica and Ulmus pumila (Tab. 3). For ranging animals metabolic protein in feces was $4.797 \pm 2.65$ $\mathrm{g} / 100 \mathrm{~g}$ of consumed food (Fig. 4). Consequently for an adult animal, consuming $1200 \mathrm{~g}$ of dry matter per day, daily metabolic protein content in feces was 57.6 $\mathrm{g} /$ individual or $9.22 \mathrm{~g} /$ individual $\left(0.71 \mathrm{~g} / \mathrm{kg}(\mathrm{BW})^{0.75}\right)$ of metabolic nitrogen. Combined with endogenous urine nitrogen $\left(0.12 \mathrm{~g} / \mathrm{kg}(\mathrm{BW})^{0.75}\right.$ per day) it amounted to $0.83 \mathrm{~g} / \mathrm{kg}(\mathrm{BW})^{0.75}$ of nitrogen $\left(5.19 \mathrm{~g} / \mathrm{kg}(\mathrm{BW})^{0.75}\right.$ of protein), which coincides to minimum daily nitrogen requirements of saiga for maintaining activity during the warm season of the year. These values are close to published estimates of nitrogen requirements $(0.41-$ $\left.0.82 \mathrm{~g} / \mathrm{kg}(\mathrm{BW})^{0.75}\right)$ for other ruminants (Robbins, 1983).

Energy costs of nitrogen for growth and weight gain adult animals are $2.5 \%$ per unit of weight gain (Agricultural research council, 1965). Taking into consider-

Table 3. Protein consumption and digestibility for saiga, 1996-2005 (reprinted from Abaturov et al., 1998, 2005).

\begin{tabular}{|c|c|c|c|c|c|c|c|c|}
\hline \multirow[t]{3}{*}{ Type of forage } & \multirow[t]{3}{*}{ Date } & \multicolumn{2}{|c|}{$\begin{array}{l}\text { Content in dry } \\
\text { matter, } \%\end{array}$} & \multicolumn{2}{|c|}{ Digestibility, \% } & \multicolumn{3}{|c|}{ Daily consumption } \\
\hline & & \multirow[t]{2}{*}{ diet } & \multirow[t]{2}{*}{ feces } & \multirow[t]{2}{*}{ apparent } & \multirow[t]{2}{*}{ true } & & \multicolumn{2}{|c|}{ digestible protein } \\
\hline & & & & & & g/anim. & g/anim. & $\mathrm{g} / \mathrm{kgBW}^{0.75}$ \\
\hline \multirow{9}{*}{$\begin{array}{l}\text { Green herb in diet (free } \\
\text { grazing)** }\end{array}$} & $4 / 12-17$ & 18.4 & 15.0 & 81 & 100 & 181.4 & 181.4 & 19.19 \\
\hline & $5 / 26-29$ & 14.8 & 15.3 & 58 & 90 & 156.9 & 141.8 & 10.50 \\
\hline & $6 / 2-6$ & 14.3 & 14.6 & 67 & 100 & 199.4 & 199.4 & 13.85 \\
\hline & $6 / 20-24$ & 14.2 & 14.0 & 73 & 98 & 150.0 & 147.1 & 14.33 \\
\hline & $7 / 27-30$ & 12.6 & 14.6 & 43 & 81 & 100.1 & 81.2 & 5.52 \\
\hline & $8 / 3-5$ & 12.0 & 14.4 & 46 & 854 & 228.3 & 195.1 & 12.04 \\
\hline & $8 / 28-31$ & 12.7 & 14.1 & 65 & 92 & 153.3 & 141.3 & 12.12 \\
\hline & $9 / 21-26$ & 13.3 & 15.7 & 50 & 76 & 113.2 & 85.8 & 8.92 \\
\hline & $12 / 1-4$ & 13.4 & 11.2 & 63 & 89 & 67.2 & 60.0 & 5.00 \\
\hline Lactuca tatarica* & $8 / 2-17$ & 17.3 & 17.8 & 54 & 74 & 130.5 & 97.1 & 9.93 \\
\hline \multirow{2}{*}{ Elm leaves* } & $-" “-$ & 10.5 & 11.0 & 54 & 88 & 110.3 & 97.2 & 9.94 \\
\hline & $-"$ - & 10.5 & 9.8 & 62 & 96 & 101.9 & 97.3 & 9.95 \\
\hline
\end{tabular}

*Feeding in balance cages

** Grazing on natural range 


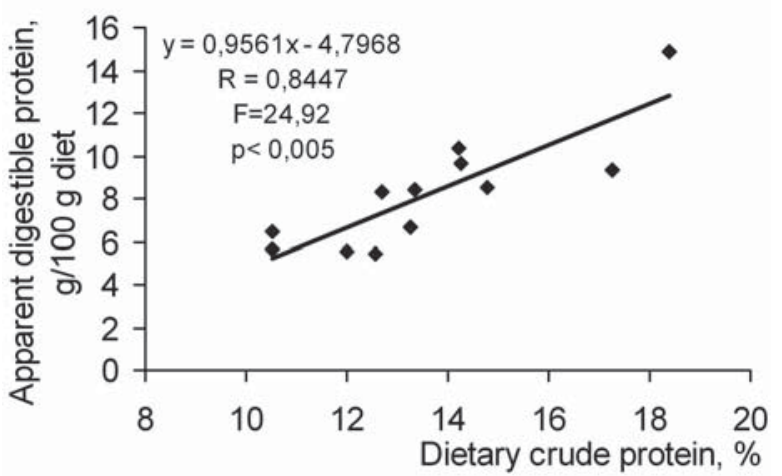

Figure 4. Relationship $(y=b x+a)$ between dietary crude protein content $(\%)$ and its apparent digestibility $(\mathrm{g} / 100 \mathrm{~g}$ feed intake) for saiga. Std. Error: $a=2.65, b=0.19$.

ation the correction for biological value of dietary nitrogen, according to which only $70 \%$ of absorbed nitrogen is used effectively (Agricultural research council 1965; McDonald et al., 1969; Robbins 1983), it is easy to calculate, that gain of $1 \mathrm{~g}$ of weight requires $0.0357 \mathrm{~g}$ of digestible nitrogen $(0.223 \mathrm{~g}$ protein). In our research when daily weight gain of grazing saiga in June, late August and in September was 530, 250 and 80 g/ind. respectively, cumulative digestible protein requirements for growth/weight gain only were 11.53, 4.80, $1.86 \mathrm{~g} /$ $\mathrm{kg}(\mathrm{BW})^{0.75}$, and for both growth/weight gain and maintaining normal activity - 16.72, 9.99 and $7.05 \mathrm{~g} /$ $\mathrm{kg}(\mathrm{BW})^{0.75}$ per day. At daily average weight gain throughout a year equal $65 \mathrm{~g} /$ individual, average requirements in digestibility protein should be equal 6.50 $\mathrm{g} / \mathrm{kg}(\mathrm{BW})^{0.75}$ per day.

During the grazing trials, consumption of crude protein varied from 60 to $199 \mathrm{~g} / \mathrm{ind}$. ( 89 to $117 \mathrm{~g} / \mathrm{kg}^{0.75}$ body weight) per day and true digestibility of protein was from 74 to $100 \%$ (Tab. 3). In this case, correlation between daily digestible protein consumption $(x)$ and dietary protein concentration $(y)$ was fairly high $(\mathrm{r}=$ 0.81 ). It can be presented in the form of regression equation $y=0.584 x+6.172$ (Fig. 5) According to the equation in order to provide a grazing animal with minimum amount of digestible protein $\left(5.19 \mathrm{~g} / \mathrm{kg}^{0.75}\right.$ body weight) required for maintenance protein concentration in plant forage needs to be not less than $9.2 \%$. This particular value reflects the minimum (threshold) level of protein content in the food, necessary to sustain nitrogen balance of grazing saiga. If other needs (growth, shedding, pregnancy and lactation) are included this level must be higher: in June, when weight gain was up to $530 \mathrm{~g} /$ ind. per day, daily digestible protein requirements $\left(16.72 \mathrm{~g} / \mathrm{kg}^{0.75}\right.$ body weight) could be satisfied only at $15.9 \%$ protein content in the ration. At the average level of annual weight gain, when requirements are $6.50 \mathrm{~g} / \mathrm{kg}(\mathrm{BW})^{0.75}$, protein content in the ration is not lower than $9.97 \%$. During lactation period protein requirements increase significantly. During the first weeks of lactation according to data for domestic sheep (Agricultural research council 1965; MacDonald et al.,

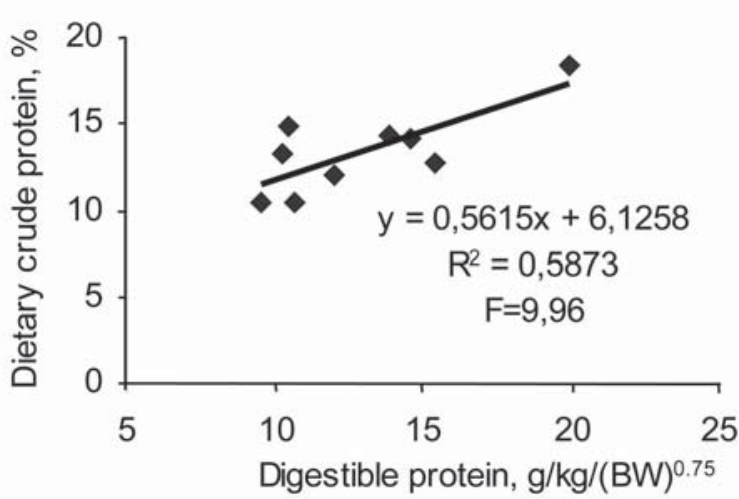

Figure 5. Relationship ( $y=b x+a)$ between dietary crude protein content $(\%)$ in free ranging saiga ration and daily consumption of digestible protein $\left(\mathrm{g} / \mathrm{kg}^{0.75}\right.$ body weight). Std. Error: $\mathrm{a}=2.07, \mathrm{~b}=0.16$.

1969), digestible protein requirements are $14.0 \mathrm{~g} / \mathrm{kg}$ $(\mathrm{BW})^{0.75}$. In this case protein content in the forage needs to be not less than $14.3 \%$.

\section{Discussion}

Our experimental data allow us to estimate minimum thresholds for energy and protein nutrition to support different levels of physiological demand, and to evaluate the sufficiency of various foods or diets based on forage quality parameters (digestibility, protein content) in the context of the saiga antelope's protein and energy demands (Tab. 4).

To provide for maintenance energy requirements (cumulative energy expenditure in a state of repose and during grazing) adult non-breeding animals need plant food with digestibility not lower than $59 \%$ and protein content not lower than $9.00 \%$. Growth and reproduction require higher quality forage. To provide for growth, digestibility of forage should be not lower than $61 \%$ with protein content $>9.80 \%$. For reproduction and lactation, digestibility must be at least $68 \%$ with protein content at least $14.00 \%$. These minimum thresholds are similar to those established for European roe deer. For roe deer, minimum estimated food digestibility and protein content for adult non-breeding animals was $60 \%$ and $5.5 \%$, respectively, while for young growing animals the minimum digestibility was $75 \%$, and for lactating females even higher (Eisfeld, 1974, 1985). According to our experimental data, nutritional value of most plant species grazed by saiga is lower than these thresholds. For Kochia prostrata, even during the peak of vegetation growth (in June), digestibility was only $49-52 \%$, of mixed steppe forbs in May-June was $54 \%$ (Tab. 2). Thus, in our energy balance trials with confined animals feeding siaga with these forages in the form of whole-plants led to negative energy balance and weight loss. In contrast, free-grazing tractable animals that were foraging on the same plants species were selecting diets of substantially higher digestibility (60- 
Table 4. Threshold parameters of forage quality for minimum energy and protein requirements of saiga antelope.

\begin{tabular}{|l|c|c|c|c|}
\hline \multirow{2}{*}{$\begin{array}{l}\text { Componenets of energy } \\
\text { and protein budgets }\end{array}$} & \multicolumn{2}{|c|}{ Requirements } & \multicolumn{2}{c|}{ Threshold parameters of forage quality } \\
\cline { 2 - 5 } & $\begin{array}{c}\text { Metabolic energy, } \\
\mathrm{MJ} / \mathrm{kg}(\mathrm{BW})^{0.75}\end{array}$ & $\begin{array}{c}\text { Digestible protein, } \\
\mathrm{g} / \mathrm{kg}(\mathrm{BW})\end{array}$ & $\begin{array}{c}\text { Minimum protein } \\
\text { content, \% }\end{array}$ & $\begin{array}{c}\text { Minimum } \\
\text { digestibility, \% }\end{array}$ \\
\hline $\begin{array}{l}\text { Maintenance of energy } \\
\text { equilibrium of free } \\
\text { existence }\end{array}$ & 0.719 & 5.19 & 9.0 & 59 \\
\hline $\begin{array}{l}\text { Maintenance of energy } \\
\text { equilibrium of free } \\
\text { existence and growth }\end{array}$ & 0.782 & 6.50 & 9.8 & 61 \\
\hline $\begin{array}{l}\text { Maintenance of energy } \\
\text { equilibrium of free } \\
\text { existence and lactation }\end{array}$ & 1.002 & 14.0 & 14.0 & 68 \\
\hline
\end{tabular}

$77 \%$ ) and positive energy balance. The high digestibility of grazed diets can be explained by the selective foraging behavior typical of saiga antelope. Free grazing saigas typically select only the most nutritious plants or parts of plants. For example, when feeding on plants of Kochia prostrata or Galatella villosa, they typically select tops of sprouts with flower buds or seeds. When feeding on Limonium gmelinii or Salsola laricina, and similar plants, they typically select for new lateral shoots and young leaves (Abaturov et al., 1998).

It is obvious that these are parts of plants of higher nutrition value, characterized with high digestibility. Thus, in our experiments with free ranging animals when the main portion (60\%) of the ration consisted of Kochia prostrata, selective grazing of only apex shoots still provided higher digestibility - up to $73 \%$ (Abaturov et al., 1998). In the experiments with confined animals in cages, they were fed with whole plants of Kochia prostrata and in this case showed lower digestibility value of 51\% (Abaturov et al., 1982). The same pattern was observed with other plant species. In the environmental conditions of the pastures investigated, Saiga almost entirely avoided gramineous plants (Abaturov et al., 1982, 1998, 2005). Their digestibility tends to be fairly low, and this explains why grasses are typically an insignificant component in the saiga's diet.

Crude protein is not apparently a nutrient likely to limit most populations of saiga antelope. In areas dominated by semidesert vegetation, where the main part of saiga population range is located, foliage of most plants is characterized by fairly high protein content throughout the year (about 14\%) (Abaturov et al., 1998). This is sufficient to meet protein requirements for maintenance, growth, and lactation (Tab. 4). Semidesert vegetation is diverse, includes both typical desert and steppe species, and has high diversity of plant forms including grasses, forbs, sub-shrubs and dwarf sub-shrubs, many of which vegetate all year round. Seasonal differences in phenological development among plants provide animals with green forage with high protein content almost throughout the year. This characteristic of semidesert vegetation sets it apart from other vegetations, particularly from steppe grass formations, which are dominated by grasses and forbs having short synchro- nous growing seasons. This is also typical of grassland (savanna) plant communities in Africa, where decrease (decline) of protein content in vegetation as low as 4$5 \%$ results in nitrogen deficiency in grazing animals (Sinclair, 1974; Arman \& Hopcraft, 1975; Berry \& Louw, 1982; Stanley Price, 1978; Abaturov et al., 1995). This explains the fact that saiga distribution range is limited to the semidesert vegetation zone with only occasional occurrence of this species in the steppe zone.

It is important to emphasize that the thresholds of food quality estimated here apply only to the warm period of the year. During the cold period saiga, like other ungulates at high latitude, lowers its level of metabolism and forage consumption. Maintenance energy requirements in winter are 1.5 times lower, and maximum consumption (until satiation) of dry plant material is 2.5 times lower than in summer (Abaturov et al., 1998). Therefore thresholds for food quality are different in winter. The quality of food in winter must be equally or even more important for sustaining positive energy balance. Substantial weight loss characteristic of saiga in winter (Bannikov et al., 1961; Abaturov et al., 1982; Lopatin et al., 1987) indicates that energy balance is negative during this period of the year. In winter the energy balance of free ranging animals was negative when forage digestibility was $56 \%$ and forage consumption was at its maximum level for the winter period. Maintaining positive energy balance in winter is possible only at very high level of forage nutrition (Abaturov et al., 1998). Indeed, energy balance of confined animals fed a grain and alfalfa hay mix (71\% digestibility) was positive (Tab. 2).

\section{Conclusions}

Analyses of the state and quality of forage resources and their influence on the saiga population during the warm period of the year showed that only non-growing adult animals could maintain positive energy balance when digestibility of consumed plant material was as low as $59 \%$. At or below this level of forage digestibility, animals cannot grow or accumulate fat. Therefore, 
providing plant resources above this level of digestibility should be considered critical to reproduction, lactation, and growth and survival of young in wild populations. Forage digestibility at $61 \%$ provides for positive energy balance and is sufficient to meet nutritional requirements for growth, but this level of digestibility is still insufficient to provide for reproduction, and particularly for lactation. To provide for all major components of the annual energy budget, including reproduction and lactation, the digestibility of consumed forage must be at least $68 \%$.

To meet the saiga's protein demand for maintenance and growth, the content of digestible protein in forage must be at least $9.8 \%$. Almost all semidesert plants are characterized with even higher content of crude protein throughout the year, and food quality in this relation is almost always above the critical threshold. Only during the lactation period, when protein requirements increase significantly to the critical level of $14.0 \%$, may forage plants contain insufficient protein.

Thus, meet an individual's nutritional demand for growth, maintenance, and reproduction, plant forage digestibility must be at least $68 \%$ and forage digestible protein content must be at least $14 \%$. Animals can survive on plants of lower digestibility (59\%) and protein content $(9.0 \%)$. However, diets this low in quality can only support maintenance and are inadequate for growth and lactation.

Given the selectivity of saiga when feeding, we conclude that normally only a portion of pasture plant mass is of necessary quality. This portion is usually not large and includes either single dominant species, or only certain parts of plants (tops, flower buds, inflorescences, new leaves and shoots). Many predominant species (majority of grasses for example) cannot be considered as forage plants of acceptable quality for saigas. Therefore, evaluation of forage availability for animals, and carrying capacity habitat should be based only on that portion of vegetation with digestibility and protein content above threshold levels, not on total standing crop biomass or even on live biomass.

ACKNOWLEDGEMENTS. Authors are very much grateful to Dr. Robert A. Riggs from Wildlife and Range Science of Boise Cascade Corporation for his valuable suggestions and general editing of the manuscript. We also thank Dr. William A. Wall of Sustainability, Inc. for his friendly notes and support of our work. Funding for this research was provided by the Russian Foundation for Basic Research (Grant 09-0400125).

\section{References}

Abaturov B.D. 2007. The population of saiga antelopes in Russia and the Problems of its preservation // Herald of the Russian Academy of Sciences. Vol.77. P.462-469 [Translated from Vestnik Rossiiskoi Akademii Nauk. Vol.77. P.785-793]
Abaturov B.D. \& Magomedov M.-R. D. 1988. [Food value and dynamics of food resources as a factor characterizing the state of populations of herbivorous mammals] // Zoologicheskii Zhurnal. Vol.67. No.2. P.223-234 [in Russian, with English summary].

Abaturov B.D., Kholodova M.V. \& Subbotin A.E. 1982. [Intensity of food consumption and digestibility in Saiga tatarica] // Zoologicheskii Zhurnal. Vol.61. No.12. P.1870-1881 [in Russian, with English summary].

Abaturov B.D., Fekadu Kassaye, Kuznetsov G.V., Magomedov M.-R.D. \& Petelin D.A. 1995. Nutritional estimate of populations of some wild free-ranging African ungulates in grassland (Nechisar national park, Ethiopia) in dry season // Ecography. Vol.8. No.2. P.164-172.

Abaturov B.D., Kolesnikov M.P., Likhnova O.P., Petrishchev B.I. \& Nikonova O.A. 1997. [Use of plant forage lignin and silica as digestibility indicators for a quantitative estimation of food consumption by free-ranging saigas] // Russian Journal of Zoology. Vol.1. No.1. P.110 117. [Translated from Zoologicheskii Zhurnal Vol.76. P.104-113]

Abaturov B.D., Petrishchev B.I., Kolesnikov M.P. \& Subbotin A.E. 1998. [Seasonal dynamics of forage resources and nutrition of saiga in natural semidesert pasture] // Uspekhi sovremennoy biologii. Vol.118. No.5. P.564584 [in Russian, with English summary].

Abaturov B.D., Kolesnikov M.P., Nikonova O.A. \& Pozdnyakova M.K. 2003. [Experience of quantitative investigation of nutrition in free-ranging mammals in natural habitat] // Zoologicheskii Zhurnal. Vol.82. No.1. P.104114 [in Russian, with English summary].

Abaturov B.D., Larionov K.O., Kolesnikov M.P. \& Nikonova O.A. 2005. [Providing of saigas (Saiga tatarica) with forage and their state in pastures with vegetation of different types] // Zoologicheskii Zhurnal. Vol.84. No.3. P.377-390 [in Russian, with English summary].

Anon. 1968. [Instruction for zonal agrochemical laboratories analysis of forage and plants] // Moscow: Izdatel'stvo "Kolos". 55 p. [in Russian].

Arman P. \& Hopcraft D. 1975. Nutritional studies on East African herbivores. 1. Digestibilities of dry matter, crude fibre and crude protein in antelope, cattle and sheep // British Journal of Nutrition. Vol.33. P.255-264.

Arnold G.W. 1985. Regulation of forage intake. Bioenergetics of wild herbivores // Hudson, R.Y. \& White, R.G. (eds.). Bioenergetics of wild Herbivores. Florida: CRC Press, Inc. Boca Raton. P.81-101.

Bannikov A.G., Zhirnov L.V., Lebedeva L.S. \& Fandeev A.A. 1961. [Biology of saiga antelope]. Moscow: Izdatel'stvo literatury, zhurnalov i plakatov. 336 p. [in Russian].

Bell R.H.V., 1971. A grazing ecosystem in the Serengeti // Scientific American. Vol.225. P.86-93.

Berry H.H. \& Louw G.N. 1982. Nutritional measurements in a population of free-ranging wildebeest in Etosha National Park // Madoqua. Vol.13. P.101-125.

Bol'shakov A.F. \& Bazykina G.S. 1974. [Natural biogeocoenosises and conditions for their existing] // Rode A.A. (ed.). Biogeocoenotic fundaments for the development of Northern Caspian semidesert. Moscow: Nauka. P.6-34 [in Russian]. 
Cook J.G., Quinlan L.G., Irwin L.L., Bryant L.D., Riggs R.A. \& Thomas J.W. 1996. Nutrition-growth relations of elk calves during late summer and fall // Journal of Wildlife Management. Vol.60, No.3. P.528-541.

Eisfeld D. 1974. Protein requirements of roe deer (Capreolus capreolus L.) for maintenance // XI Congress of International Union of Game Biologists. No.11. P.133138.

Eisfeld D. 1985. Anspruche von Rehen an die Qualität ihrer Nahrung // XXII Congress of International Union of Game Biologists. Brussels. P.1027-1034.

Fennessy P.F., Moore G.H. \& Gorson I.D. 1981. Energy requirements of red deer // Proceedings of New Zealand Society of Animal Production. Vol.41. P.167-173.

Jiang Z. \& Hudson R.J., 1992. Estimating forage intake and energy requirements of free-ranging wapiti (Cervus elaphus) // Canadian Journal of Zoology. Vol.70. P.675679.

Gallup W.D., Hobbs C.S. \& Briggs H.M. 1945. The use of silica as a reference substance in digestion trials with ruminants // Journal of Animal Science. Vol.4. P.68-71.

Gordeeva T.K. \& Larin I.V. 1965. [Nature vegetation of Caspian semidesert as forage reserve for livestock] // Moscow: Nauka. 160 p.

Hudson R.J. \& Christopherson R.J. 1985. Maintenance metabolism // Hudson R.Y. \& White R.G. (eds.). Bioenergetics of wild Herbivores. Boca Raton, Florida: CRS Press, Inc. P.121-142.

Kaloshnikov A.P. \& Kleimenov N.I. 1985. [Standards and rations of livestock]. Moscow: Agropromizdat [in Russian].

Kolesnikov M.P. \& Abaturov B.D. 1997. [Silicon forms in plants and their quantitative determination] // Uspekhi sovremennoi biologii. Vol.117. No 5. P.534-548 [in Russian, with English summary].

Lopatin V.N., Abaturov B.D. \& Rossolovskiy S.V. 1987. [Mathematical model of energetic processes of saiga growth] // Zhurnal obshchei biologii. Vol.48. No.4. P.513-524 [in Russian, with English summary].

Magomedov M.-R.D.\& Yarovenko Yu.A. 1997. [Intensity of consumption and digestibility of food in East Caucasian Tur (Capra cylindricornis)] // Zoologicheskii Zhurnal. Vol.76. No.2. P.243-250 [in Russian, with English summary].

McDonald P., Edwards R.A. \& Greenhalgh J.F.D. 1969. Animal nutrition. Edinburgh and London: Oliver \& Boid. $479 \mathrm{p}$.

Mould E.D. \& Robbins Ch.T. 1981. Nitrogen metabolism in elk // Journal of Wildlife Management. Vol.45. No.2. P.323-334.

Owen-Smith N. \& Cooper S.M. 1989. Nutritional ecology of a browsing ruminant, the kudu (Tragelaphus strepsiceros), through the seasonal cycle // Journal of Zoology. London. Vol.219. P.29-43.

Regelin W.L., Schwartz Ch.C. \& Franzmann A.W. 1987. Effects of forest succession on nutritional dynamics of moose forage // Swedish Wildlife Research. Supplement. 1. Part. 1. P.247-263.

Robbins Ch.T., Prior R.L., Moen A.N. \& Visec W.J. 1974. Nitrogen metabolism of white-tailed deer // Journal of Animal Science. Vol.38. No.1. P.186-191.

Robbins, Ch.T. 1983. Wildlife feeding and nutrition. N.Y.Æ Academic press. 343 p.

[Ruminants' requirements in nutrients and energy]. 1968. // Izdatel'stvo Kolos, Moscow. 414 pp. [in Russian]. Translated from Agricultural Research Council. 1965. The nutrient requirements of farm livestock. No.2. Ruminants, Technical reviews and summaries. London: H.M. Stationery Office.

Schwartz Ch.C., Regelin W.L. \& Franzmann A.W. 1987. Protein digestion in moose // Journal of Wildlife Management. Vol.51. No.2. P.352-357.

Simpson A.M., Webster A.J.F., Smith J.S. \& Simpson C.A. 1978. The efficiency of utilization of dietary energy for growth in sheep (Ovis aries) and red deer (Cervus elaphus) // Comparative Biochemistry and Physiology. Vol.69. P.1166-1175.

Sinclair A.R.E. 1974. The natural regulation of buffalo populations in East Africa. IV. The food supply as a regulating factor, and competition // East African Wildlife Journal. Vol.12. P.291-311.

Sinclair A.R.E., Fryxell J.M. \& Caughley G. (eds.). 2006. Wildlife ecology, conservation and management. Oxford: Blackwell Publishing. 469 p.

Sinclair A.R.E., Krebs C.I. \& Smith T.N.M. 1982. Diet quality and food limitation in herbivores: the case of the snowshoe hare // Canadian Journal of Zoology. Vol.60. P. 889-897.

Smith S.H., Holter J.B., Hayes H.H. \& Silver H. 1975. Protein requirement of white-tailed deer fawns // Journal of Wildlife Management. Vol.39. No.3. P.582-589.

Stanley Price M.R. 1978. The nutritional ecology of coce's hartebeest (Alcelaphus buselaphus cocei) in Kenya // Journal of Applied Ecology. Vol.15. P.33-49.

Streeter C.L. 1969. A review of techniques used to estimate the in vivo digestibility of grazed forage // Journal of Animal Science. Vol.29. P.757-768.

Suttie J.M., Fennessy P.F., Veenvliet B.A., Littlejohn R.P., Fisher M.W., Corson I.D. \& Labes R.E. 1987. Energy nutrition of young red deer (Cervus elaphus) hinds and a comparison with young stags // Proceedings of New Zealand Society of Animal Production. Vol.47. P.111-114. 